\title{
Human Capital is a Competitive Advantage of Businesses: Analysis of Automobile Firms of Pakistan
}

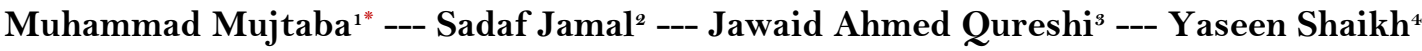 \\ ${ }^{1,2,{ }^{2}}$ Department of Management Sciences, SZABIST, Karachi, Pakistan. \\ Email:smmujtaba14@gmail.com \\ ${ }^{4} M S$-Project Management, MUISTD, MUET, Jamshoro, Pakisatan.
}

\begin{abstract}
The purpose of conducting this research is to examine the significance of Human Capital (HC) in automobile sector of Pakistan because leading automobile firms of the world have claimed that HC has major role beyond their success. This is quantitative research which is based on philosophy of positivism. The primary data of this study was collected from management and crucial employees of main Light Transport Vehicle automobile firms of Pakistan. Result of this research indicates that there is strong impact of human capital on firm performance; it performs the function of oxygen in hard-hitting competition where every firm is busy to take a lead in open market. This study is very constructive not only for the automobile industry but this work will also create awareness and need of HC in all manufacturing firms of Pakistan in the scenario of globalization.
\end{abstract}

Keywords: Human capital (HC), Competitive advantage, Automobile

Licensed: This work is licensed under a Creative Commons Attribution 4.0 License.

Funding: This study received no specific financial support.

Competing Interests: The authors declare that they have no competing interests.

\section{Introduction}

Human Capital (HC) is ultimate weapon of business firms' globalization where everyone is busy to launch innovative product to take lead in competition. HC is only resource of firm who conceptualized creative ideas to develop innovative products by using their knowledge, skills and experience; it gives edge to business firm against its competitors (Wang, Shieh and Wang, 2008). The worldwide fast growing competition and economic integration have increased the concentration of organizations on the development of $\mathrm{HC}$ (Butt and Katuse, 2017). Think creatively, diagnose problem and establish novel solution of customer needs indicate the uniqueness of Human Capital; it performs the role of oxygen for firm in competition (Aryee et.al, 2016). $\mathrm{HC}$ is not only one time solution of firm performance but it is long tenure competitive advantage if firm continue to invest on the HC development and keep its moral high through motivation (Liang and Gang, 2017).

According to Liu et.al, (2017) the China is one of the emerging economy of the world and the Chinese firms are competitive almost in every field of business due to innovation and reduction in price of product and it happened due to HC. The race of competition, where frequent changes are required to meet the customer needs, the talent war has taken the place among revivals, where primarily focus of firms management is to align functions of Human Resource department with continuously developing the Human Capital for favourable long term position of firm against its competitors, therefore, in the light of global competition, the critical strategy behind the firm performance is "One Company- One way to Success- Consistently Valuing People”, like any fine gardener recognizes, to encourage healthy growth, beside to fertilizing as well as watering, he also has to prune and weed, however, in many companies, Human Resources Professionals spend 
large efforts on planting, watering and occasionally fertilizing it, but particularly no one is cutting away deadwood or development inhibiting underbrush (Bartlett, Christopher and Ghoshal, 2002).

According to Morris, et, al, (2017) due to globalization, the firms need to understand and address the functions of Human Resources Management at micro level to develop the their Human Capital. Whereas, firms needs to invest on employees to develop their knowledge and keep them motivated so that they can show their full commitment and loyalty with firm through generate new ideas, and identify the hurdles and solution-in progress of firm (Aleo and Sergi, 2017). Lee and Mah (2017) argued that economic incorporation at worldwide has carried broad change in the industry of automobile to deliver more comfortable, cost-effective or high quality automobiles to its customers at national level as well as catch the attention of other markets customers at regional level to raise the profitability, there is example of Korea, Taiwan, China and Indonesia.

Pakistan automobile industry has great potential to perform import role in development of country as same industry is performing remarkably in east Asia countries, the Finance-Ministry (2017) has explained in its Economic Survey Report (2016- 2017), that the Pakistan automobile industry can contribute major role in the GDP of country because presently, it is one of the fast growing and having reasonable contribution in the GDP of Pakistan, but there is great potential in this industry to improve the production to attract local as well as foreign (i.e. South Asian countries) customers through improvement of firms performance with help of HC; in this connection the Government of Pakistan has given tariff incentives in new auto policy to attract new investments in this industry, now its depend upon the automobile firms to improve their performance bring innovate and maintain the quality of vehicles to attract local and foreign customers to avoid import of vehicles. Production-Ministry (2017) has explained in its Industries and Production Report (2016- 2017), that it is great need of time that automobile firms of Pakistan must deliver the innovative and quality of products to decrease the import of vehicles. $\mathrm{HC}$ has shown great potential to maintain firm performance for extensive time and considered as ultimate economic resource of firm (Tripathy, Alana and Sahoo, 2017).

There is dearth of academic research in automobile industry of Pakistan, especially in the context of HC importance in firm performance to attract local and foreign customers, this is age of competition where firms must focus on the mind of customers and produce only those products which provide something new which must catch the attention of the customers (Butt and Katuse, 2017). This is quantitative research which is based on philosophy of positivism. The primary data of this study was collected from management and crucial employees of major Light Transport Vehicle automobile firms of Pakistan (i.e. Indus Motors, Pak Suzuki Co. and Atlas Honda Motorbikes)

\section{Literature Review}

2.1. Human Capital

According to Vidotto et. Al, (2017) the Human Capital is the type of intellectual capital, which is combination of unique knowledge and motivational characteristics such as education and skills, thoughts and association which formed into the mind as well as in the actions of person. HC consists to those employees who equipped with distinctive knowledge, expertise and capability to change the situation of market in the favour of their employer (Lin, et. Al, 2017). Aryee et.al, (2016) they argued that the success behind the renowned manufacturing corporations (like Apple, Honda, Toyota, IBM or Sony) is based on the philosophy of gathering best talent (HC) to remain dominate on market. Choices of "Make" or "Buy" available to business firms make their HC pool (Quinn, 2005).

Morris, et. Al, (2016) there is need to understand the importance of $\mathrm{HC}$ in context of firm survival in competition, which is rapidly changing. Whenever top management invest additional resources on potential employees, their worth will automatically increase in terms of unique talent, and that uniqueness performs important role in competition (Lin, et. Al, 2017). Business firms are functioning in competitive environmentdynamic and complex, and this environment has much focused on the significance on HC- high potential, knowledge, skills, innovative, who helps in development of organizational strategy and having capability to develop routes for the implementation of strategy and having the potential to execute the strategy towards improve the firm performance (Partouvakis and Karakasnaki, 2017). Tripathy, Alana and Sahoo (2017) broadly, they called HC as complete package or force of combined knowledge of different fields which has established to move the firm effectively on zigzag track of competition towards destination. In sequel perusal of different literature work in domain, the concept of $\mathrm{HC}$ is consists of two dimensions such as knowledge and motivation, the knowledge dimension is embedded in employee, whenever employees leave the organization it will go with him; whereas motivational dimension is attached with position when employee leave the organization it will be automatically detached from him.

\subsection{Knowledge}

Knowledge is vast term, which create relationship between knower and known, here knower is subject (i.e. individual) whereas known is object (i.e. anything). In context of HC, it focused only on scare knowledge (i.e. intellectual and critical thinking, technical knowhow, having ability to identify the customer needs, cultural barriers, market trends), and this knowledge embedded in employees through relevant domain education, skills, experience and professional networks (Morris, Snell and Bjorkman, 2016). Education and skills are essential obligation of $\mathrm{HC}$, which comes through educational institutions, long and short terms trainings, and 
by doing the repetition of action, it is not fixed at particular point, it is continuous process and based on innovation of technology or paradigm in the market, which compel to organization to invest and train their potential employees in new technology or pattern to take lead in competition (Bartlett, Christopher and Ghoshal, 2002). Experience is also important because it provides practical understanding and implication of knowledge, as the experience increase, it strengthen the knowledge, it is a lived or on job experience which enable the employee to encounter different problems and resolve them with best market practices in real scenario, and leaning of employee will increase as many as individual face the challenges and resolves them with best practices (Quinn, 2005). The Professional network is one of the key component to explore new ideas and business, it is combination of professionals who hold and share diverse knowledge with each other not only within organization but also outside of the organization because the external network also performs indispensable role into corporation's capability to explore new ideas and new production, and failure to discover latest ideas as well as knowledge can lead towards poor performance (Rogan and Mors, 2017)

\subsection{Motivation}

"Can do" and "will do" are two different conceptual dimensions of HC, "Can do" is the capacity of employee to perform the work and it represent the knowledge, whereas "Will do" is the willingness of employee to perform the work and it represent the motivational dimension, both dimensions interdependent on each other to explore new idea to understand the customers' need and become the competitive advantage of firm's performance (Aryee, et, al, 2016). There is need of motivational factor which energize the employee to use his knowledge and go some extra miles than other employees, generate some new ideas and perform central role in the operations of organization, actually the motivational factor boost the speed, constant selfrenewal and flexibility (Bartlett, Christopher and Ghoshal, 2002). The firms need those employees who have knowledge, they retain them longer period of time by keeping them motivate all the time (Liang and Gong, 2017). Compensation and benefits is one of important motivational element which financially bound to employee to stay in firm, in fact, the agreement on compensation and benefits between employer and employee is mutual investment, if employer invest more than the expectations from employee must be high whereas if employer invest less than expectations must be less from employee, in less expectation case the employee will just performed his duties as per job description, he will not go extra mile to explore new ideas, (Aryee, et. al, 2016). Barrachina, Cabrales and Cabrera (2017) they described that, in the process of developing $\mathrm{HC}$ the organization firstly, select the high potential employees from available human resources, secondly, the organization spend sufficient amount on their development through different trainings, thirdly, once they complete their trainings, then the organization increase their responsibilities (i.e. Job enrichment) along with promotions and sufficient increase in their compensation and benefits. Make choice of career focused and energetic employees who accept the challenges and wanted to do more, then set up team of experts who help and coach to these rising star of firm (Davis, 2017). Aryee, et. al, (2016) they defined that innovative behaviour of employee is based on seeds of empowerment and conducive environment, which give individual free hand to utilizing firm's resources and peace of mind to do brainstorming at every time to explore the customer need. Organizations whose aim is innovation, they expect high commitment from potential employees by providing them learning environment to develop new ideas (Barrachina, Cabrales and Cabrera, 2017). According to Davis, (2017), this is era of talent war, where established organizations have focused to maximize HC by creating dynamic work climate, broadly, it has reduced the bureaucracy and increase decentralized structure (i.e. Team work) so that decisions can be taken at the spot and avoids unnecessary procedures.

\subsection{Competitive Advantage}

Before 1980 s the tangible assets were considered the competitive advantage and more focus was given to production to meet demand, but is the era of globalization- where every firm is compelled to bring innovative product in market to leads in market, and the innovation is outcome of mind of human who bring new ideas on basis of his knowledge (Lepak and Snell, 1999). Barrachina, Cabrales and Cabrera (2017) they argued that innovation is based mainly on two important phases (i.e. generation phase and adoption phase), generation phase includes acknowledgment of opportunity, do research, design, development, marketing as well as distribution, whereas adoption phase is based on two processes (i.e. initiation process and implementation process), initiation process includes all actions that attached to identify the need, such as aware of a likely or potential innovation, assessing its appropriateness, make judgment and decide to take up (adopt) the innovation, while implementation focus to take all actions that relates to innovation. The conceptual framework of this is study is prepared according nature and objectives of research. 


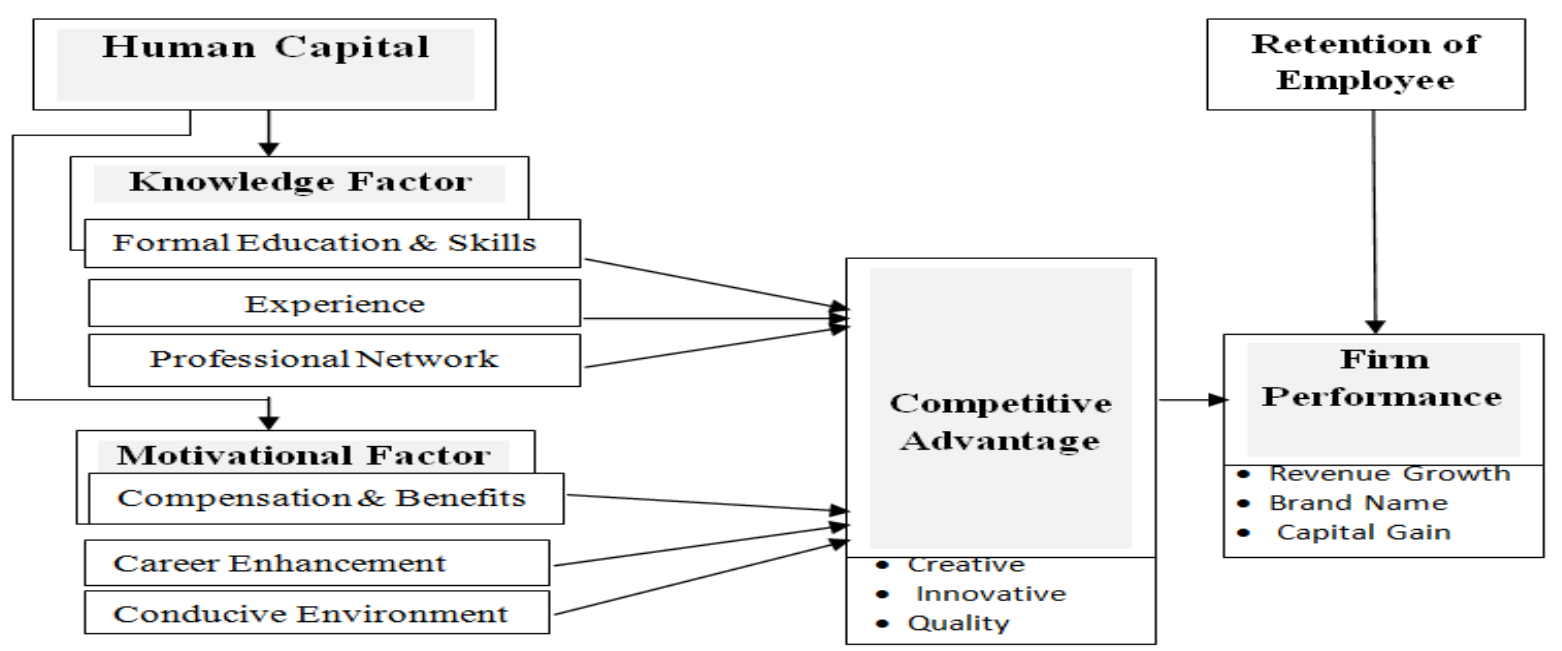

Source: Self developed and it is equated like.

Figure-1. Conceptual Framework.

Firm Performance $=f($ Knowledge $($ Capability $) \times$ Motivation $)$

\section{Methodology}

This is quantitative and cross sectional research study which is based on philosophy of positivism. The primary data of this study was collected from management and crucial employees of major Light Transport Vehicle automobile firms of Pakistan (i.e. Indus Motors, Pak Suzuki Co. and Atlas Honda Motorbikes). Population of this research work is consist of management and crucial employees, who were working in three well known automobile firms of Pakistan and deals with light transport vehicles such as Atlas Honda, Pak Suzuki and Indus Motors. The sample size of this was study 201 and convincing sampling method was used to collect data. Firstly, a close ended questionnaire was designed and refined after discussions with domain experts to confirm the validity of contents and context. Once the validity of questionnaire was finalized then a pilot test was conducted from 30 respondents to check the reliability before starting comprehensive survey. The reliability result of pilot test was .78 which indicated that the reliability of research work for further process to conduct survey.

\section{Data Analysis and Discussion}

4.1. Reliability

Primary data was collected from 201 respondents through comprehensive survey. Firstly, the reliability analysis was done by using SPSS. Results of same are exhibited at Table 1 which indicated that overall reliability (Chronback's Alpha) is $0.926>.07$ whereas are individuals variables reliability are ranging from 0.706 to $0.850>.07$. It depicts that the scale used for this research is satisfactorily reliable for testing hypotheses.

Table-1. Reliability.

\begin{tabular}{l|c|c}
\multicolumn{3}{c}{ Table-1. Reliability. } \\
\hline Variable & No. of Items & Chronbach's Alpha Value \\
\hline Overall Reliability & $\mathbf{3 0}$ & $\mathbf{. 9 2 6}$ \\
\hline Formal Education and Skills (FES) & 3 & .706 \\
\hline Experience (EX) & 3 & .765 \\
\hline Professional Network (PN) & 3 & .776 \\
\hline Compensation and Benefits (CB) & 3 & .748 \\
\hline Career Enhancement (CE) & 3 & .723 \\
\hline Empowerment and Conducive Environment (ECE) & 3 & .737 \\
\hline Competitive Advantage (CA) & 6 & .843 \\
\hline Firm Performance (FP) & 6 & .850 \\
\hline *Reliability is good at 0.7>. & &
\end{tabular}

\subsection{Correlation Analysis}

Correlation test was applied to examine the relationship among variables the correlation, all results of test are exhibiting significant value of .000 as shown at Table 2. It depicts that there is sufficient relationship among all variables. The strong correlation in context of independent variables and dependent variable is identified between Compensation and Benefits and Firm Performance with Pearson value of .640 with significance level at .000, whereas the Competitive Advantage as mediating variable has strongest relation with Firm Performance, the correlation value of this relation is identified with value of. 721 as Pearson Correlation and it is significant at .000. 
Table-2. Correlations.

\begin{tabular}{l|l|l|l|l|l|l|l|l}
\hline & & FES & EX & PN & CB & CE & ECE & CA \\
\hline $\begin{array}{l}\text { Firm } \\
\text { Performance }\end{array}$ & $\begin{array}{l}\text { Pearson } \\
\text { Correlation }\end{array}$ & $.584^{* *}$ & $.597^{* *}$ & $.597^{* *}$ & $.640^{* *}$ & $.611^{* *}$ & $.619^{* *}$ & $.721^{* *}$ \\
\hline & Sig.(2-Tailed) & .000 & .000 & .000 & .000 & .000 & .000 & .000 \\
\hline & $\mathrm{N}$ & 201 & 201 & 201 & 201 & 201 & 201 & 201 \\
\hline
\end{tabular}

**.Correlation is significant at the 0.01 level (2-tailed).

\subsection{Regression Analysis}

According to nature of research, the conceptual framework was divided into two models for the purpose of regression analysis to get accurate results such as Model-1: To check the impact of independent variables on mediating variable and Model-II: To check the impact of mediating variable on dependent variable.

Firstly, the regression analysis was applied to on Model-1 to check the impact of independent variables on mediating variable. Results are indicating at Table 4 that Coefficient is $\mathrm{F}=44.955$ with significant value of $.000 \mathrm{~b}$, it shows that overall impact of model is significant. Whereas table no.3 indicating that $\mathrm{R}=.763$ this shows that independent variables are impacting on mediating variable, this shows that $76.3 \%$ variance in mediating variable because of independent variables.

Table-3. Model Summary.

\begin{tabular}{l|l|l|l|l}
\hline Model & R & R Square & Adjusted R Square & Std Error of the Estimate \\
\hline 1 & $.763 \mathrm{a}$ & .582 & .569 & .575 \\
\hline a. $\quad$ Predictors:(Constant),FES,EX,PN,CB,CE,ECE.
\end{tabular}

Table-4. ANOVA a.

\begin{tabular}{|c|c|c|c|c|c|c|}
\hline \multicolumn{2}{|c|}{ Model } & \multirow{2}{*}{$\begin{array}{l}\text { Sum of Squares } \\
89.073\end{array}$} & \multirow{2}{*}{$\begin{array}{l}\text { df } \\
6\end{array}$} & \multirow{2}{*}{$\begin{array}{l}\text { Mean Square } \\
14.845\end{array}$} & \multirow{2}{*}{$\begin{array}{l}\mathbf{F} \\
44.955\end{array}$} & \multirow{2}{*}{$\begin{array}{l}\text { Sig. } \\
.000 b\end{array}$} \\
\hline & Regression & & & & & \\
\hline 1 & Residual & 64.065 & 194 & .330 & & \\
\hline & Total & 153.138 & 200 & & & \\
\hline
\end{tabular}

b. Predictors:(Constant), FES,EX,PN,CB,CE,ECE.

\begin{tabular}{|c|c|c|c|c|c|c|}
\hline \multirow{2}{*}{\multicolumn{2}{|c|}{ Model }} & \multicolumn{2}{|c|}{$\begin{array}{l}\text { Unstandardized } \\
\text { Coefficients }\end{array}$} & \multirow{2}{*}{$\begin{array}{l}\text { Standardized } \\
\text { Coefficients } \\
\text { Beta }\end{array}$} & \multirow[t]{2}{*}{$\mathbf{t}$} & \multirow[t]{2}{*}{ Sig. } \\
\hline & & B & Std. Error & & & \\
\hline \multirow[t]{7}{*}{1} & (Constant) & .399 & .126 & & 3.164 & .002 \\
\hline & Formal Education and Skills (FES) & .145 & .061 & .163 & 2.376 & .018 \\
\hline & Experience (EX) & .074 & .064 & .083 & 1.159 & .248 \\
\hline & Professional Network (PN) & .006 & .063 & .006 & .090 & .929 \\
\hline & Compensation and Benefits (CB) & .067 & .071 & .074 & .936 & .350 \\
\hline & Career Enhancement (CE) & .224 & .067 & .242 & 3.356 & .001 \\
\hline & Empowermentand CE(ECE) & .311 & .063 & .343 & 4.917 & .000 \\
\hline
\end{tabular}

Further, Table 5 results are indicating significant value of three independent variables such as Formal Education and Skills= Beta is .163 and Significance is .018, Career Enhancement= Beta is .242 and Significance is .001, and Empowerment and Conducive Environment= Beta is .343 and Significance is .000. It means the raise of 1 in Empowerment and Conducive Environment then Competitive Advantage will increase by $34.3 \%$, and same is other two significant variables. Whereas remaining three independent variables results are insignificant.

Secondly, the regression analysis was again applied on Model-II to check the impact of mediating variable on dependent variable. Results are indicating at Table 7 that Coefficient is $\mathrm{F}=215.929$ with significant value of .ooob, it shows that overall impact of model-II if significant. Whereas at table no. 6 the $\mathrm{R}=.721$ this shows that mediating variable is impacting on dependent variable, this shows that $72.1 \%$ variance in dependent variable because of mediating variable.

Table-6. Model Summary.

\begin{tabular}{l|l|l|l|l}
\hline Model & $\mathbf{R}$ & R Square & Adjusted R Square & Std Error of the Estimate \\
\hline 1 & $.721 \mathrm{a}$ & .520 & .518 & .628 \\
\hline b. Predictors:(Constant),Competitive Advantage.
\end{tabular}


Table-7. ANOVA a.

\begin{tabular}{l|l|l|l|l|l|l}
\hline \multicolumn{2}{l|}{} & Sum of Squares & df & Mean Square & F & Sig. \\
\hline & Regression & 85.120 & 1 & 85.120 & 215.929 & $.000 \mathrm{~b}$ \\
\hline 1 & Residual & 78.447 & 199 & .394 & & \\
\hline
\end{tabular}

d. Predictors:(Constant), Competitive Advantage.

Table-8. Coefficients a.

\begin{tabular}{|c|c|c|c|c|c|c|}
\hline \multirow{2}{*}{\multicolumn{2}{|c|}{ Model }} & \multicolumn{2}{|c|}{$\begin{array}{l}\text { Unstandardized } \\
\text { Coefficients }\end{array}$} & \multirow{2}{*}{$\begin{array}{l}\text { Standardized } \\
\text { Coefficients } \\
\text { Beta } \\
\end{array}$} & \multirow[t]{2}{*}{$\mathbf{t}$} & \multirow[t]{2}{*}{ Sig. } \\
\hline & & $\mathrm{B}$ & Std. Error & & & \\
\hline & (Constant) & .605 & .126 & & 4.789 & .000 \\
\hline 1 & Perceived Performance & .746 & .051 & .721 & 14.695 & .000 \\
\hline
\end{tabular}

Further results are indicating at Table 8 that the significant value of mediating variable i.e. Beta is .721 and Significance is .000, it means the raise of 1 in Competitive Advantage then Firm Performance will increase by $72.1 \%$.

\subsection{Sobel Test}

For further cross check the regression analysis results, the Sobel test was applied to reconfirm the results and check the effect of independent variables on dependent variable through mediating variable. Results of Sobel test are exhibited at Table 9.

Table-9. Sobel Results.

\begin{tabular}{l|l|l}
\hline Variable & Sobel test statistic & Two-tailed probability Sig. \\
\hline Formal Education and Skills & 2.34627065 & $0.01896233^{*}$ \\
\hline Experience & 1.15265451 & 0.24905222 \\
\hline Professional Network & 0.09523608 & 0.92412732 \\
\hline Compensation and Benefits & 0.94170435 & 0.34634403 \\
\hline Career Enhancement & 3.25923492 & $0.00111713^{*}$ \\
\hline Conducive Environment & 4.67732803 & $0.00000291^{*}$
\end{tabular}

Sobel test results are indicating that there is significant impact of Formal Education and Skills, Career Enhancement and Conducive Environment (Independent variable) on Firm Performance (Dependent variable) through Competitive Advantage (Mediating variable). Whereas there is no significant impact of Experience, Professional Network and Compensation and Benefits on Firm Performance through Competitive Advantage.

The overall regression analysis depicted that Human Capital has strong impact on firm performance, it is performing major role in competition which exist among automobile sector. Education and Skills, Career Enhancement and Empowerment and Conducive Environment are important factors of Human Capital, which make employees capable and motivate them to go extra miles and perform major role for their firms in competition.

\section{Conclusion}

This research study illustrates that $\mathrm{HC}$ has major role in completion, it develop creative thinking and resolve the problems of Automobile firms to lead in globalization. HC consists of those employees who acquired distinguish knowledge and have motivation to think beyond the box and identify as well as develop those products which meet the customers' needs. HC is not only focus on present need of customers but also predict the future needs of market and provide firm long sustainability in business competition. There is great need for automobile and other manufacturing firms of Pakistan to understand the significance of HC as compare to other resources in firm performance, so that maximum main manpower of firms may be converted in experts to run the firms in effective way. Further, firms need to focus and enhance the education and skills of employees, focus on career development of employees, delegate the powers to their employees to empower them to take decision at their own end and provide them conducive environment, so that they can develop creative ideas for the development of innovative and quality products to attract attention of local customer as well as foreign customers. In this study only light transport vehicle manufacturing units were focused whereas automobile sector is vast field and there is great need to conduct comprehensive research study on complete automobile sector which should include heavy transport vehicle and spare parts manufacturing units of Pakistan so that it can contribute progressive role in growth of economy. 


\section{References}

Aryee, S., Walumbwa, F. O., Seidu, E. Y. \& Otaye, L. E. (2016). Developing and leveraging human capital resource to promote service quality: Testing a theory of performance. Journal of Management, 42(2): $480-499$.

Aleo, V. \& Sergi, B. S. (2017). Human factor: The competitive advantage driver of the EU's logistics sector. International Journal of Production Research, 55(3): 642-655.

Barrachina, M., Cabrales, A. \& Cabrera, R. (2017). How do employment relationships enhance firm innovation? The role of human and social capital. The International Journal of Human Resource Management, 28(9): 1363-1391.

Bornay-Barrachina, M., López-Cabrales, A. \& Valle-Cabrera, R. (2017). How do employment relationships enhance firm innovation? The role of human and social capital. The International Journal of Human Resource Management, 28(9): 1363-1391.

Bartlett, C. A. \& Ghoshal, S. (2002). Building competitive advantage through people. MIT Sloan Management Review, 43(2): 34-41.

Butt, M. A. \& Katuse, P. (2017). International human resource management practices in automotive industry in Pakistan: Implications for economic growth. International Journal of Business and Management, 12(2): 136-144.

Davis, P. J. (2017). How HR can create competitive advantage for the firm: Applying the principles of resource-based theory. Human Resource Management International Digest, 25(2): 4-6.

Finance-Ministry, (2017). Economic survey report (2016- 2017). Ministry of Finance Government of Pakistan.

Lee, J. I. \& Mah, J. S. (2017). The role of the government in the development of the automobile industry in Korea. Progress in Development Studies, 17 (3): 1-16.

Lepak, D. P. \& Snell, S. A. (1999). The human resource architecture: Toward a theory of human capital allocation and development. Academy of Management Review, 24(1): 31-48.

Lin, C., Yu-Ping Wang, C., Wang, C. Y. \& Jaw, B. S. (2017). The role of human capital management in organizational competitiveness. Social Behavior and Personality: An International Journal, 45(1): 8192.

Liang, J. \& Gong, Y. (2017). Human resource development investment in Chinese private firms: Strategic choice and institutional perspectives. Management and Organization Review, 13(1): 57-83.

Liu, D., Gong, Y., Zhou, J. \& Huang, J. C. (2017). Human resource systems, employee creativity, and firm innovation: The moderating role of firm ownership. Academy of Management Journal, 60(3): 11641188.

Morris, S. S., Alvarez, S. A., Barney, J. B. \& Molloy, J. C. (2017). Firm-specific human capital investments as a signal of general value: Revisiting assumptions about human capital and how it is managed. Strategic Management Journal, 38(4): 912-919.

Morris, S., Snell, S. \& Björkman, I. (2016). An architectural framework for global talent management. Journal of International Business Studies, 47(6): 723-747.

Pantouvakis, A. \& Karakasnaki, M. (2017). Role of the human talent in total quality management-performance relationship: An investigation in the transport sector. Total Quality Management \& Business Excellence, 28(9-10): 959-973.

Production-Ministry, (2017). Review of industries and production of Pakistan: 2016- 2017. Published by Government of Pakistan. pp: 1-123.

Quinn, J. B. (2005). The intelligent enterprise a new paradigm. Academy of Management Perspectives, 19(4): 109-121.

Rogan, M. \& Mors, M. L. (2017). Managerial networks and exploration in a professional service firm. Organization Studies, 38(2): 225-249.

Tripathy, T., Gil-Alana, L. \& Sahoo, D. (2017). Effect of intellectual capital on firms ${ }^{-}{ }^{-}$competitive advantage condition: An empirical investigation in India. Review of Economics \& Finance, Better Advances Press, Canada, 8: 61-78.

Tripathy, T., Gil-Alana, L. \& Sahoo, D. (2017). Effect of intellectual capital on firms ${ }^{-}{ }^{-}$competitive advantage condition: An empirical investigation in India. Review of Economics \& Finance, Better Advances Press, Canada, 8: 61-78.

Vidotto, A., Morais, A. T., Ribeiro, M. R., Pacca, C. C., Terzian, A. C., Gil, L. H. \& Nogueira, M. L. (2017). Systems biology reveals NS4B-cyclophilin an interaction: A new target to inhibit YFV replication. Journal of Proteome Research, 16(4): 1542-1555.

Wang, I.-M., Shieh, C. J. \& Wang, F.-J. (2008). Effect of human capital investment on organizational performance. Social Behavior and Personality, 36 (8): 1011-1022. 